\title{
Post-enlargement emigration and new EU members' labor markets
}

\section{Outmigration has contributed to increasing wages and decreasing unemployment in the new EU member states but may also cause skills shortages}

Keywords: outmigration, emigration, labor market, EU enlargement, labor mobility, transition economies

\section{ELEVATOR PITCH}

The recent EU enlargements into Central and Eastern Europe and increased labor mobility within the Union provide a unique opportunity to evaluate the labor market effects of emigration. Outmigration has contributed to higher wages for stayers, as well as to lower unemployment in the source country. However, emigration has also exacerbated skills shortages in some sectors, as well as mismatches between skills and jobs.

\section{KEY FINDINGS}

\section{Pros}

๑ Outmigration has reduced the excess supply of labor and lowered unemployment.

๑ Outmigration has increased the wages of stayers, especially for socio-economic groups that have become relatively scarce.

$\oplus$ There are potential benefits from return migrants with enhanced human capital.

( ) Labor migrants send cash to their home economies.

๑ Labor migration may act as an adjustment mechanism during periods of macroeconomic shocks and its importance increases as more countries join the Euro currency zone.
Emigration and labor markets in three new EU member states

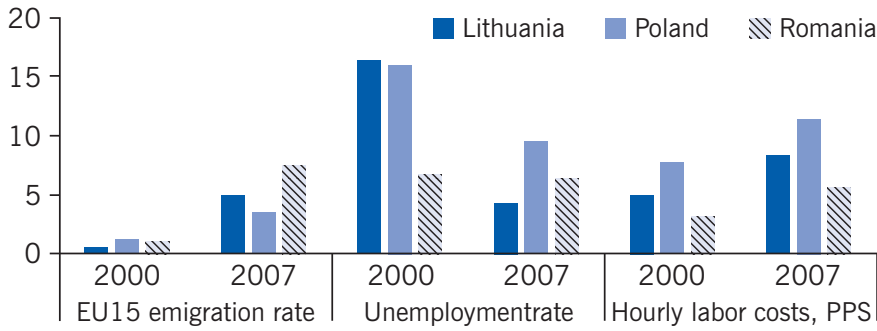

Note: PPS, purchasing power standard

Source: Author's calculations, based on data from [1] and Eurostat.

\section{Cons}

- Outmigration may amplify labor and skills shortages in certain sectors.

- Outmigration has exacerbated mismatches between skills and jobs.

- Outmigration may lead to brain drain and brain waste.

- Inflationary pressure may be attributable to the consequences of emigration.

- Outmigration exacerbates demographic pressures and pressures on public budgets.

\section{AUTHOR'S MAIN MESSAGE}

Post-enlargement EU emigration relieves sending countries of some of their excess labor, reducing unemployment and boosting wages. The positive effects for wages are particularly pronounced for socio-economic groups that have become relatively scarce. However, outmigration may also amplify labor and skills shortages and mismatches in the labor market, which will intensify as labor demand grows. Policies should focus on training and retraining, better matching between skills and jobs, education reform, labor force participation, and productivity gains, as well as relevant migration and return migration policies. 


\section{MOTIVATION}

The effect of outmigration on labor markets is an important policy issue. It has become particularly relevant for the new Central and Eastern European members that joined the EU in 2004 and 2007. Even though not all EU15 members immediately allowed the free movement of workers into their countries, the new members experienced large outflows of labor after accession that reduced their labor supply. The worry was that these countries would lose their youngest and most productive workers (brain drain). But labor migration can also be an adjustment mechanism by absorbing excess labor. This paper focuses on the effects of emigration on wages and employment.

The experience of the new EU members provides an opportunity to ascertain the effects of emigration on the sending countries, which had low wages and an oversupply of labor before accession. The Transitional Arrangements, which gave EU15 countries flexibility in opening up their labor markets to the new member states, created a natural experiment enabling the identification of the true effects of migration (see EU eastern enlargements and transitional arrangements). Because the overall economic gains from removing barriers to migration are substantial, the migration experience of the new EU members offers potential lessons for all countries.

\section{EU eastern enlargements and transitional arrangements}

In May 2004, eight Central and Eastern European countries (EU8) joined the EU (EU15)-the Czech Republic, Estonia, Hungary, Latvia, Lithuania, Poland, Slovakia, and Slovenia-together with Cyprus and Malta. Bulgaria and Romania (EU2) followed in January 2007, and Croatia in July 2013. To quell fears of huge waves of emigration from the poorer and geographically close Central and Eastern European countries, the EU15 members introduced the Transitional Arrangements to restrict the free movement of workers from the EU8 and EU2 countries. These arrangements were based on a " $2+3+2$ " formula: For the first two years, access to the labor markets of the EU15 countries depended on their national laws; the duration could be extended for a further three years, and then for another two years, if countries could demonstrate serious disruptions in their labor markets.

In 2004, only Ireland, Sweden, and the UK opened their labor markets to EU8 workers. Austria and Germany removed the remaining restrictions for EU8 workers in 2011. Several countries applied restrictions for the EU2 workers, while Spain unprecedentedly reintroduced restrictions in July 2011 "due to serious disturbances in its labor market". The restrictions on EU2 workers ended in January 2014.

The differential implementation of the Transitional Arrangements set up a unique natural experiment. Some researchers conclude that they have diverted some of the migrants from traditional destination countries such as Germany and Austria toward the Republic of Ireland and the UK. Others argue that other factors, such as the English language and favorable labor market conditions, have also played an important role in directing migration.

Furthermore, while immigration from the EU8 to the "closed" German labor market has been taking place despite the formal restrictions, using self-employment as an entry channel, Sweden has attracted a relatively small number of migrants, despite its open borders. 


\section{DISCUSSION OF PROS AND CONS}

\section{Expected benefits and potential challenges}

In a simple textbook model of a competitive labor market with constant labor demand, a reduction in the labor supply due to outmigration leads to a wage increase for the workers left behind. However, the real picture may be complicated by additional factors. First, differences in skills between migrants and stayers matter. It is important whether migrants' skills substitute for or complement those of workers who stay. The wages of a skills group that becomes relatively scarce due to emigration are expected to increase. Second, there is an indirect effect on the demand for labor: An open economy accommodates changes in skills composition by adjusting its exports to make greater use of a relatively abundant factor, thus offsetting the wage increase in the long term. Third, an additional offsetting factor is the potential immigration of labor, which would compensate for the scarce labor resource.

A substantial oversupply of labor was common among the post-socialist countries of Central and Eastern Europe, and resource reallocation was one of the main labor market challenges during transition. As a result of labor-shedding and low job creation, unemployment rose to unprecedented levels in the 1990s. This initial phase of enterprise restructuring and jobless growth was followed by an expansion phase, as productivity gains enabled firms to increase output and hire more workers [2]. In contrast to the early stage of transition, when growth was constrained by demand, at the time of enlargement it was the supply side (labor shortages) that imposed constraints [2]. For the new member states, accession to the EU coincided with a time of economic growth and rising demand. Real gross domestic product (GDP) was growing at an average rate of 5.6\% a year in the EU8 and 6.5\% a year in the EU2 during 2004-2007.

Moreover, the labor content of growth was increasing as well, as a result of restructuring, improvements in the investment climate, and accession to the EU [2]. Successful job creation was accompanied by a substantial decline in unemployment and a significant increase in vacancy rates by the mid-2000s. Labor and skills shortages became evident in several sectors, particularly in construction and health care, among others [2], [3], [4]. Unemployed workers often lacked the skills needed to fill vacancies. These job-skill mismatches reflected, at least in part, obsolete human capital inherited from the days of planned economies and ineffective education systems [2]. Wages rose substantially as a result of the tight labor market, the Baltic countries experiencing the largest wage growth and the sharpest drop in unemployment. This strong wage growth, combined with cash sent home by migrants, credit expansion, and money from EU funds, contributed to inflation [4].

Outmigration might have contributed to these developments in the labor market. If emigrants were unemployed before moving, or if those who stayed took the jobs previously held by employed emigrants, emigration might have efficiently relieved sending countries of excess labor, and contributed to lower unemployment and to enhance wage growth. However, if emigrants possessed relevant skills, labor shortages might have been amplified, and emigration might have contributed to inflationary pressure. It is difficult to disentangle the net effect of outmigration. The next section discusses these issues, looking at the available evidence. 


\section{Evidence}

Evidence on the labor market effects of emigration is primarily descriptive. The few available econometric studies that estimate the effects of out-migration even worldwide are mostly for migration to the US from Mexico. The EU eastern enlargements provide another opportunity for estimating these effects, and several studies exploit this natural experiment. One of the main challenges when estimating the effects of out-migration is related to data: Measuring emigration is difficult. Because migrants often fail to deregister from residence registries when moving abroad, official emigration statistics are often underestimated. One way to overcome this data problem is to use data from the receiving countries on migrants for a particular sending country. Another is to use household surveys that collect information on household members who are currently abroad. In addition, labor force surveys that capture current migrants and stayers usually have information on employment status only from only the previous year, which is a very short-term perspective. This section discusses the results from recent studies for the new EU member states, isolating the effects of emigration from those of the overall restructuring in the region.

The effect of emigration on the home country labor market generally depends on the scale and composition of migrant flows. Overall, around $1.8 \%$ of the EU 8 population (see Figure 1) and $4.1 \%$ of the EU2 population (see Figure 2) moved to the EU15 over 2004-2009 and 2007-2009, although there was considerable variation by country. Romania, Lithuania, and Bulgaria had the highest emigration rates [1].

Figure 1. Pre-crisis emigration to the EU15 and labour markets in the EU8, averages

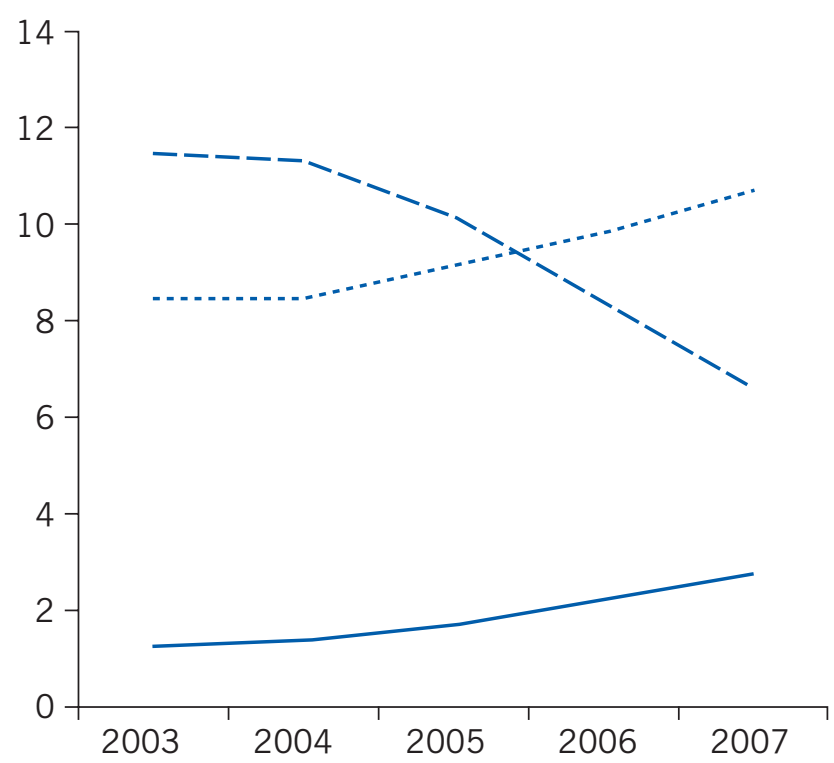

— Emigration stocks in the EU15, - - Average unemployment -..--Average hourly labor in $\%$ of the sending region rate, $\%$ costs, PPS

Note: PPS, purchasing power standard

Source: Author's calculations, based on data from Holland, D., T. Fic, A. Rincon-Aznar, L. Stoke, and P. Paluchowski. Labour Mobility within the EU-The Impact of Enlargement and the Functioning of the Transitional Arrangements. Final Report. Study for the DG Employment, Social Affairs and Inclusion, European Commission. London: National Institute of Economic and Social Research, 2011 [1], and Eurostat. 
Figure 2. Pre-crisis emigration to the EU15 and labour markets in the EU2, averages

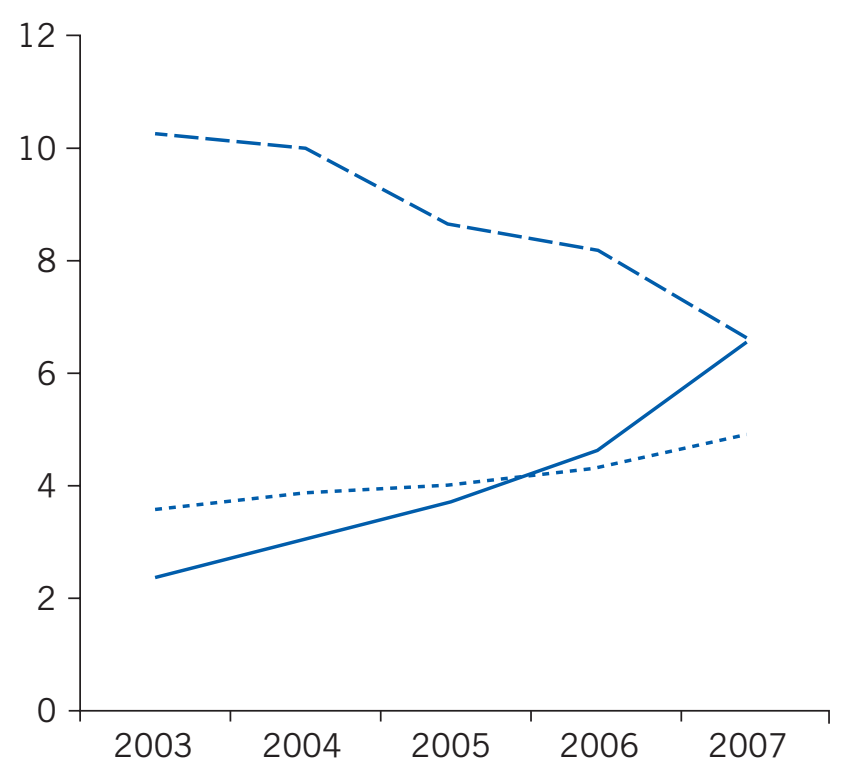

_ Emigration stocks in the EU15, - - Average unemployment -..-- Average hourly labor in $\%$ of the sending region rate, $\%$ costs, PPS

Note: PPS, purchasing power standard

Source: Author's calculations, based on data from Holland, D., T. Fic, A. Rincon-Aznar, L. Stoke, and P. Paluchowski. Labour Mobility within the EU-The Impact of Enlargement and the Functioning of the Transitional Arrangements. Final Report. Study for the DG Employment, Social Affairs and Inclusion, European Commission. London: National Institute of Economic and Social Research, 2011 [1], and Eurostat.

Generally, emigrants were young and relatively skilled, most having intermediate skills. There were some exceptions, however, such as the larger representation of low-educated emigrants from the EU2. Many of these migrants stayed abroad only temporarily. Migrants from the new member states were overwhelmingly successful in finding employment abroad, although they worked mostly in low-skilled occupations. This down-skilling carries a potential risk of losing one's qualifications (brain waste) and suggests that their human capital might not have been fully transferrable across borders [5], [6]. There also appears to be an additional indirect effect of emigration on increasing the incentives to invest in upgrading or acquiring new skills for those who stay and still have the option to emigrate. This incentive effect, combined with the return of more skilled migrants, may offset the negative consequences of the brain drain and lead to a higher level of schooling in the country and thus to higher wages (for some evidence of increased enrollment in higher education in the new member states, see, for example, [5]).

\section{Macroeconomic studies}

Macroeconomic simulations based on theoretical models using aggregate migration data (taking into account the variety of the effects on the sending and receiving countries) point to a substantial overall gain to the entire EU area from post-enlargement migration. A study of migration scenarios of EU8 workers between 2004 and 2007 found a $0.2 \%$ increase in aggregate GDP for the EU (€24 billion) [6]. However, in the 
sending countries, GDP declined $1.1 \%$ in the long term owing to the loss of labor. While labor market effects were small for receiving countries, in the short run wages rose an estimated $0.3 \%$ in the new member countries (with all skills groups experiencing a rise), and the unemployment rate fell 0.4 of a percentage point (with the largest decline among the less skilled). Poland, Slovakia, and Lithuania had the largest wage increases.

In line with the theoretical model, in the long term, after capital has adjusted, migration has essentially no effect on aggregate wages and aggregate unemployment. There is, however, a significant decline in unemployment among the less skilled, even in the long term.

A 2011 study that compiled migration data over 2004-2009 found the long-term loss of GDP for the EU8 to be slightly higher (1.25\%) than the loss calculated in a study mentioned above and a much larger long-term loss for the EU2 (7.55\%) [1]. GDP in Romania, for example, was estimated to be 3.6\% lower in 2009 than it would have been had there been no emigration. Emigration reduced unemployment in 2009 by 0.27 of a percentage point in the EU8 and 0.54 of a percentage point in the EU2, with the largest declines in Romania, Poland, and Estonia. The long-term effects are again negligible. For countries with available data on wages, emigration led to an increase in wages by $0.44 \%$ in 2009 in the Czech Republic, $0.68 \%$ in Hungary, and $2.73 \%$ in Poland, with slightly smaller long-term effects.

\section{Country studies}

This section discusses three country studies that estimate the labor market effects of emigration for Poland, Lithuania, and Moldova. Poland, along with Romania, is the largest labor-sending country among the new EU member states in absolute terms. Lithuania is an excellent case study for evaluating the effects of emigration because of its high share of emigration relative to the labor force. Finally, Moldova, an out-of-sample case study, is also a good country for comparative analysis because the restructuring is still ongoing and, while it has an enhanced cooperation relationship with the EU under the Eastern Partnership. Nevertheless, despite emigration restrictions, Moldova has one of the highest emigration rates in the world.

\section{Eastern Partnership}

The Eastern Partnership is an enhanced cooperation agreement between EU member states and six countries of Eastern Europe and Southern Caucasus: Armenia, Azerbaijan, Belarus, Georgia, Moldova, and Ukraine. It is founded on common values, such as democracy and the rule of law, respect for human rights and freedoms, and commitment to market economy. The rationales and long-term goals of this initiative, launched in 2009, are to strengthen integration and cooperation, in particular to "promote democracy and good governance, strengthen energy security, promote sector reform and environment protection, encourage people-to-people contacts, support economic and social development, and offer additional funding for projects to reduce socio-economic imbalances and increase stability."

Eastern Partnership. Online at: http://eeas.europa.eu/eastern/index_en.htm [Accessed April 2, 2014]. 
Poland. The stock of Polish citizens staying abroad for longer than three months reached a peak of almost 2.3 million (6.6\% of the total population) in 2007 before declining slightly to around 2.0 million in 2010, a remarkable increase from just 786,000 in 2002 (based on Polish Statistical Office data) [3]. These temporary migrants headed primarily for other EU countries (1.6 million were in the EU27 in 2010). These numbers are consistent with those of other researchers, who report that around 1.5 million Poles resided in the EU15 in 2009 [1].

There were some important changes in destinations between 2002 and 2007. Germany, a traditional destination for Polish migrants, lost popularity, while the UK and Republic of Ireland attracted most of Poland's post-accession emigrants. Post-accession emigrants are younger than previous emigrant cohorts, and they are better educated, a majority possessing vocational education and almost $20 \%$ having had tertiary education [3], [7]. More than $90 \%$ are employed while abroad. A descriptive analysis of Polish emigration concludes in line with [2] that it had only moderate effects on unemployment and wages in Poland, with the favorable business cycle and restructuring effects largely responsible for the decline in unemployment and the growth in wages [3]. There are signs that Poland is becoming an immigrant-receiving country, with immigrants filling vacancies in sectors such as agriculture, construction, and household services [3].

A study using data from the Polish Labor Force Survey on individuals who are absent from the household at the time of the survey and have been residing abroad for longer than three months finds a somewhat lower level of emigration [7]. The study constructed region- and year-specific emigration rates, and then estimated the effect of emigration from a particular region on wages in a particular skills group defined by education level. Emigration had on average a statistically significant (although relatively small) positive effect on the wages of stayers, with the largest effects for workers with intermediate skills-the group that experienced the largest reduction through emigration. By contrast, low-skilled workers experienced no wage gains.

Lithuania. A study of the effects of post-accession emigration on Estonia, Latvia, and Lithuania concludes that outmigration was not the only cause of falling unemployment and growing wages, and that strong employment growth and a rising number of job vacancies did more to lower unemployment and boost wages [4] (see also [2]). Since migrants were predominantly medium- and low-skilled workers, the wages of stayers with these skills rose, narrowing the wage differential between high- and low-skilled workers [4].

Lithuania had one of the highest post-accession emigration rates in the EU, with more than $5 \%$ of its population residing in the EU15 countries in 2009 [1], and some $9 \%$ of its labor force holding Irish or UK work permits between 2004 and 2007 [8]. An evaluation of the effects of this large labor supply reduction using data from the Republic of Ireland and the UK, the two main receiving countries-and exploiting the natural experiment context-finds a significant positive effect of emigration on the wages of stayers [8], [9]. A 1 percentage point increase in the emigration rate raises real wages $0.67 \%$-and groups with the largest emigration rates faced the largest increase [8]. In this model, emigration explains $8 \%$ of the overall wage increase in Lithuania between 2002 and 2006 , and up to $16 \%$ of the wage increase for men. 
The research finds no evidence of a significantly different wage effect across skill and education levels, but does find that emigration caused an increase in the wages of young workers, defined as those with less than 20 years of labor market experience [9]. This means that emigration explains between $10 \%$ and $30 \%$ of young workers' wage increases. These findings indicate also that, as in other transition economies, skills mismatches are important in Lithuania. Because of obsolete skills, workers who obtained their human capital under socialism could not easily substitute for the younger emigrants.

Moldova. Moldova, an out-of-sample case study, is interesting for several reasons:

- First, despite the institutional barriers to migration, emigrants account for $17 \%$ of the country's population and almost $30 \%$ of the labor force, clearly making it one of the largest emigrant-sending countries in the world in relative terms [10].

- Second, Moldova's economic transformation included a severe economic contraction at the beginning of the transition, followed by stagnation. If resource reallocation and labor-shedding are still taking place in some sectors, this could lead to shrinking labor demand in those sectors and increasing labor demand in expanding sectors [10]. Consequently, the effect on wages may differ across sectors, and declining demand for labor resources may offset any wage increases induced by emigration.

A 2011 study using household survey data estimates a significant positive effect of emigration on wages in Moldova over 2000-2006 [10]. The effect was larger for men and in the construction and service sectors, where labor demand was rising, than in agriculture or industry, where labor demand was declining. These results point to an important differential effect across sectors attributable to the economic transformation and to differences in labor demand in different sectors.

\section{LIMITATIONS AND GAPS}

Despite great policy relevance, the effect of emigration on the labor market outcomes of those who stay behind remains largely underresearched. Research has focused mostly on the labor market effects of immigration on receiving countries, while studies of those on sending regions have been mostly on the impacts of remittances, that is the cash sent home by migrants and its effects, including labor supply behavior of household members who stayed as well as the examination of brain drain.

Reliable evidence on the labor market effects of emigration is scarce, mainly because of a shortage of good data. Since emigrants rarely de-register when leaving the sending country, studies have to rely on data from receiving countries or use survey information provided by household members on those who are living abroad. Both approaches have limitations. Data from receiving countries cannot account for all migrant destinations, while household survey data do not include emigrants from single-individual households or households in which all members have emigrated. Further studies are needed on the new member states, including on the effects of emigration on other member states, as well as on the impact of the recent economic downturn. More research is also needed on the effects of return migration. And the effect of the lifting of transitional restrictions for the EU8 in 2011 and the EU2 in 2014 is also of great policy interest. 


\section{SUMMARY AND POLICY ADVICE}

The available evidence suggests that outmigration has generally contributed to an average wage increase for workers who stayed, with young workers, men, and workers with intermediate skills benefiting from the largest increases. Workers who stayed behind may have enjoyed increased bargaining power, enabling them to negotiate higher wages. Moreover, emigration has relieved sending countries of excess labor, and has contributed to lower unemployment. The role of migration as an adjustment mechanism is important during periods of economic downturn, such as the recent economic crisis, and will be even greater as more new EU members join the single currency zone.

But outmigration was not the only cause of these developments, as new EU members were already enjoying strong employment growth and rising labor demand at the time of accession, owing to the favorable business cycle and successful restructuring. On the negative side, emigration amplified labor and skills shortages, particularly in sectors such as construction and health care. Accordingly, labor shortages and demographic pressures will become more apparent as these economies return to their pre-crisis growth path.

These findings suggest important policy implications. Particularly important are: promoting training and retraining to enhance obsolete skills, and to improve the matching of skills with jobs, and reforming education systems. Given the demographic challenges, policies that stimulate labor force participation and increase productivity are also needed.Moreover, since labor shortages are likely to be filled by immigrant labor, accommodating immigration policies is important.

Finally, a large share of emigration from the new member states is temporary. Return migration is expected to alleviate the negative consequences of the brain drain and to ease demographic and fiscal pressures. Returners also bring enhanced human capital, and contribute to employment and entrepreneurship. Policies to stimulate return migration, to keep links with the diaspora, and to facilitate labor market reintegration of return migrants and their families are therefore desirable.

\section{Acknowledgments}

The author thanks two anonymous referees and the IZA World of Labor editors for many helpful suggestions on earlier drafts. Anzelika Zaiceva is a participant in the IZA project "EU Enlargement and the Labor Markets" funded by the IZA, and gratefully acknowledges its support.

\section{Competing interests}

The IZA World of Labor project is committed to the IZA Guiding Principles of Research Integrity. The author declares to have observed these principles.

(c) Anzelika Zaiceva 


\section{REFERENCES}

\section{Further reading}

Clemens, M. A. "Economics and emigration: Trillion-dollar bills on the sidewalk?" Journal of Economic Perspectives 25:3 (2011): 83-106.

Kahanec, M., and K. F. Zimmermann. EU Labor Markets after Post-Enlargement Migration. Berlin: Springer, 2010.

Kahanec, M., and K. F. Zimmermann. Migration and the Great Recession: Adjustments in the Labour Market of an Enlarged European Community. Berlin: Springer, 2015.

Zaiceva, A., and K. F. Zimmermann. "Scale, diversity, and determinants of labour migration in Europe." Oxford Review of Economic Policy 24:3 (2008): 428-452.

Zaiceva, A., and K. F. Zimmermann. "Returning home at times of trouble? Return migration of EU enlargement migrants during the crisis." In: Kahanec, M., and K. F. Zimmermann (eds). Migration and the Great Recession: Adjustments in the Labour Market of an Enlarged European Community. Berlin: Springer, 2015.

\section{Key references}

[1] Holland, D., T. Fic, A. Rincon-Aznar, L. Stoke, and P. Paluchowski. Labour Mobility within the EU-The Impact of Enlargement and the Functioning of the Transitional Arrangements. Final Report. Study for the DG Employment, Social Affairs and Inclusion, European Commission. London: National Institute of Economic and Social Research, 2011.

[2] Rutkowski, J. From the Shortage of Jobs to the Shortage of Skilled Workers: Labor Markets in the EU New Member States. IZA Discussion Paper No. 3202, 2007.

[3] Kaczmarczyk, P. "Labour market impacts of post-accession migration from Poland." In: Free Movement of Workers and Labour Market Adjustment: Recent Experiences from OECD Countries and the European Union. Paris: OECD Publishing, 2012; pp. 173-194.

[4] Hazans, M., and K. Philips. "The post-enlargement migration experience in the Baltic labor markets.” In: Kahanec, M., and K. F. Zimmermann (eds). EU Labor Markets after Post-Enlargement Migration. Berlin: Springer, 2010; pp. 255-304.

[5] Kahanec, M., A. Zaiceva, and K. F. Zimmermann. "Lessons from migration after EU enlargement." In: Kahanec, M., and K. F. Zimmermann (eds). EU Labor Markets after PostEnlargement Migration. Berlin: Springer, 2010; pp. 3-45.

[6] Baas, T., H. Brücker, and A. Hauptmann. "Labour mobility in the enlarged EU: Who wins, who loses?" In: Kahanec, M., and K. F. Zimmermann (eds). EU Labor Markets after Post-Enlargement Migration. Berlin: Springer, 2010; pp. 47-70.

[7] Dustmann, C., T. Frattini, and A. Rosso. The Effects of Emigration from Poland on Polish Wages. Centre for Research and Analysis of Migration (CREAM) Discussion Paper No. 29/12, 2012.

[8] Elsner, B. "Does emigration benefit the stayers? Evidence from EU enlargement." Journal of Population Economics 26:2 (2013): 531-553.

[9] Elsner, B. "Emigration and wages: The EU enlargement experiment." Journal of International Economics (Forthcoming).

[10] Bouton, L., S. Paul, and E. R. Tiongson. The Impact of Emigration on Source Country Wages: Evidence from the Republic of Moldova. World Bank Policy Research Working Paper No. 5764, 2011.

The full reference list for this article is available from the IZA World of Labor website (http://wol.iza.org/articles/post-enlargement-emigration-and-new-EU-members-labormarkets). 